\title{
Comparison of antioxidant properties of Cyathula prostrata Linn and Achyranthes aspera Linn grown in Sri lanka
}

\author{
Dissanayake DPA ${ }^{1}$, Sivaganesh $\mathrm{S}^{2}$, Tissera $\mathrm{MHA}^{3}$, Handunnetti $\mathrm{SM}^{4}$ and Arawwawala $\mathrm{LDAM}^{5}$ \\ ${ }^{1}$ Department of ShalyaShalakya, Institute of Indigenous Medicine, University of Colombo, Sri Lanka \\ ${ }^{2}$ Department of Surgery, Faculty of Medicine, University of Colombo, Sri Lanka \\ ${ }^{3}$ Department of Dravyaguna, Gampaha Wickramarachchi Ayurveda Institute, University of Kelaniya, Sri Lanka \\ ${ }^{4}$ Institute of Biochemistry Molecular Biology and Biotechnology, University of Colombo, Sri Lanka \\ ${ }^{5}$ Research \& Development Complex, Industrial Technology Institute, Halbarawa Gardens, Thalahena, Malabe, Sri Lanka
}

\begin{abstract}
Cyathula prostrata Linn (Family:Amaranthaceae) is widely used to stop the bleeding of patients suffering from piles (hemorrhoids). C. prostrata cannot be found universally and it grows only in areas which has wet climatic condition. Achyranthes aspera Linn is also belonging to plant family Amaranthaceae and Sri Lankan Ayurvedic physicians are used this plant as a substitute for $C$. prostrata. Not like $C$. prostrata, $A$. aspera is found on road sides, field boundaries and waste places as a weed throughout the country. As Ayurvedic pharmacodynamics properties are similar in both $C$. prostrata and $A$. aspera an attempt was made to evaluate the suitability of using $A$. aspera as a substitute for C. prostrata in terms of (a) phytochemical screening and (b) in vitro antioxidant activities. Results revealed that saponins, phenolic compounds, flavonoids and alkaloids were present in both plants. Antioxidant activities of ABTS [2,2-azino-bis (3 ethylbenzothiazoline-6-sulfonicacid) diammonium salt], DPPH (1,1-diphenyl-2-picrylhydrazyl) and FRAP (Ferric reducing antioxidant power) are almost similar in both $C$. prostrata and $A$. aspera. However, total phenolic content, total flavonoid content and ORAC (Oxygen radical absorbance capacity) activities were higher in $C$. prostrata hot water extract than that of $A$. aspera. In conclusion, considering the similarities of phytochemical constituents and antioxidant activities of two plants, $A$. aspera can be used as a substitute for $C$. prostrata.
\end{abstract}

\section{Introduction}

Piles (Hemorrhoids) are swelling or inflammation that develops inside and around the back passage (anal canal) [1]. Etiology of hemorrhoids may be increased straining, hypertension, obesity or pregnancy [2]. In Sri Lanka, decoction of Cyathula prostrata Linn (Sinhala name: Rath-Karalheba), which belong to the plant family Amaranthaceae is widely used to stop the bleeding of patients suffering from hemorrhoids. C. prostrata is a decumbent herb to $1 \mathrm{~m}$, branched from base; stem striate, stoloniferous, rooting at lower nodes, thickened at nodes reddish or purplish. Leaves are opposite and bisexual flowers are in groups of 3-5 [3]. However, C. prostrata cannot be found universally and it grows only in area which has wet climatic condition. C. prostrata gets easily spoil with the atmospheric humidity unless it is stored in air tight bags. Therefore, C. prostrata is not available in the local market. Achyranthes aspera Linn (Sinhala name Gas-Karalheba) is also belonging to plant family Amaranthaceae. Sri Lankan Ayurvedic physicians use this plant as a substitute for C. prostrata. A. aspera is found on road sides, field boundaries and waste places as a weed throughout in Sri Lanka. It is a perennial herb, with a few spreading branches, cylindrical, hairy, internodes $8-12.5 \mathrm{~cm}$ long, striate, nodes are bulged, often tinged with pink colour. Leaves are simple, and flowers are arranged in long spikes form in inflorescences with white small flowers [3]. Decoctions made out of whole plants of C. prostrata and $A$. aspera are used as a remedy for hemorrhoids. Ayurvedic pharmacodynamics properties are similar in both C. prostrata and A. aspera for instance both plants have potency of ushna (hot), pacify vata and kaphadosha. Therefore, an attempt was made to evaluate the suitability of using A. aspera as a substitute for C. prostrata in terms of (a) phytochemical screening and (b) in vitro antioxidant activities.

\section{Materials and methods}

\section{Collection and identification of plant materials}

Whole plants of C. prostrata and A. aspera were collected from home gardens in Gampaha district, Sri Lanka between October to December 2014. The plant materials were identified and authenticated by Prof. M.H.A. Tissera, Head of Dravyaguna Department, Gampaha Wickramarachchi Ayurveda institute, University of Kelaniya, Sri Lanka. Voucher specimens (CP-1 and AS -1) were deposited in Dravyaguna Department, Institute of Indigenous Medicine, University of Colombo, Sri Lanka.

\section{Preparation of hot water extract}

Each plant material (60 g) was added to a vessel containing 1.92 $\mathrm{L}$ of distilled water and reduced the volume up to $240 \mathrm{ml}$ under mild heat. After that, extract was filtered and filtrate was concentrated under vacuum and freeze dried (yields: $10.5 \% \mathrm{w} / \mathrm{w}$ and $12.2 \% \mathrm{w} / \mathrm{w}$ for $C$. prostrata and A. aspera respectively).

${ }^{\star}$ Correspondence to: Dissanayake DPA, Senior lecturer, Department of Shalya Shalakya, Institute of Indigenous Medicine, University of Colombo, Sri Lanka, E-mail: drdpadissanayake@gmail.com

Key words: Cyathula prostrata Linn, Achyranthes aspera Linn, antioxidants, phytochemicals

Received: July 09, 2018; Accepted: July 20, 2018; Published: July 23, 2018 


\section{Phytochemical screening}

Phytochemical screening tests for saponins, phenols, flavonoids, glycoside and alkaloids were performed to hot water extracts of $C$. prostrata and A. aspera according to the methods described by Yadar and Agarwala [4].

\section{Total flavonoid content (TFC)}

Different concentrations $(125,62.5,31.25,15.62,7.81$ and 3.90 $\mu \mathrm{g} / \mathrm{ml}$ ) of C. prostrata and A. aspera hot water extracts were prepared in methanol. One hundred microliters of $2 \%$ aluminium chloride in methanol solution was added to $100 \mu \mathrm{l}$ of C. prostrata or A. aspera. The mixture was incubated at room temperature $\left(25 \pm 2{ }^{\circ} \mathrm{C}\right)$ for 10 minutes and absorbance was recorded at $415 \mathrm{~nm}$. Pre-plate reading was recorded before adding the aluminium chloride solution. Five different concentrations of quercetin were used to construct the standard curve. TFC of extracts expressed as mg quercetin equivalents per gram of extract [5].

\section{Total polyphenolic content (TPC)}

Different concentrations $(125,62.5,31.25,15.62,7.81$ and $3.90 \mu \mathrm{g} /$ $\mathrm{ml}$ ) of C. prostrata and A. aspera hot water extracts were prepared in methanol. Twenty microliters of C. prostrata or A. aspera hot water extract was added to $110 \mu \mathrm{l}$ of ten times diluted freshly prepared Folin-Ciocalteu reagent and preplate reading was taken. Then seventy microliters of sodium carbonate solution was added to the mixture and incubated at room temperature $(25 \pm 20 \mathrm{C})$ for 30 minutes. The absorbance was recorded at $765 \mathrm{~nm}$. Five different concentrations of gallic acid were used to construct the standard curve. TPC of extracts expressed as mg gallic acid equivalents per gram of extract [6].

\section{1,1-diphenyl-2-picrylhydrazyl (DPPH) assay}

Reaction volumes of $200 \mu \mathrm{l}$ of DPPH radical $(125 \mu \mathrm{M})$ and $50 \mu \mathrm{l}$ of different concentrations $(125,62.5,31.25,15.62$ and $7.81 \mu \mathrm{g} / \mathrm{ml})$ of $C$. prostrata or A. aspera hot water extract mixed and incubated at $25 \pm$ $2{ }^{\circ} \mathrm{C}$ for 15 minutes and the absorbance was recorded at $517 \mathrm{~nm}$. Five different concentrations of Trolox were used to construct the standard curve. Results were expressed as Trolox equivalents antioxidant capacity in mg Troloxequivalents per gram of extract on dry weight basis [7].

\section{2,2-azino-bis (3 ethylbenzothiazoline-6-sulfonicacid) diam- monium salt (ABTS) assay}

A stable stock solution of ABTS radical cation was produced by reacting $10 \mathrm{mM}$ of ABTS in potassium persulfate at $37^{\circ} \mathrm{C}$ for $16 \mathrm{~h}$ in dark. Reaction volume of $200 \mu \mathrm{l}$, containing $40 \mu \mathrm{M}$ of $\mathrm{ABTS}^{+}$radical and 50 $\mu \mathrm{l}$ of $31.25,15.62,7.81,3.90$ and $1.95 \mu \mathrm{g} / \mathrm{ml}$ of different concentrations of C. prostrata or A. aspera hot water extract was incubated at $25 \pm 2{ }^{\circ} \mathrm{C}$ for $10 \mathrm{~min}$. and the absorbance was recorded at $734 \mathrm{~nm}$. Five different concentrations of Trolox were used to construct the standard curve. Results were expressed as Trolox equivalents antioxidant capacity in mg Trolox equivalents per gram of extract on dry weight basis [8].

\section{Oxygen radical absorbance capacity (ORAC)}

In brief, reaction volume of $200 \mu \mathrm{l}$, containing $100 \mu \mathrm{l}$ of $4.8 \mu \mathrm{M}$ fluorescein and $50 \mu \mathrm{l}$ of 15.62 and $7.81 \mu \mathrm{g} / \mathrm{ml}$ of different concentrations of C. prostrata or A. aspera hot water extract was pre-incubated at 37 ${ }^{\circ} \mathrm{C}$ for $10 \mathrm{~min}$. followed by addition of $50 \mu \mathrm{l}$ of potassium persulphate, 2,2'-azobis (2-amidinopropane) dihydrochloride (AAPH; $40 \mathrm{mg} / \mathrm{ml}$ ), to each well to initiate the reaction. The plate was placed on the fluorescent microplate reader set with excitation and emission at $494 \mathrm{~nm}$ and 535 $\mathrm{nm}$ and decay of fluorescein was recorded in 1 minute interval for 35 minutes. Trolox was used as a standard antioxidant. ORAC activities of the extracts were calculated by comparing the net area under curve of fluorescein decay between the blank and the extracts. Results were expressed as ORAC values in mg of Trolox equivalents gram of extract on dry weight basis [9].

\section{Ferric reducing antioxidant power (FRAP)}

In brief, reaction volume of $200 \mu \mathrm{l}$ containing $150 \mu \mathrm{l}$ working FRAP reagent, $30 \mu \mathrm{l}$ acetate buffer and $20 \mu \mathrm{l}$ of $31.25 \mu \mathrm{g} / \mathrm{ml} \mathrm{C.} \mathrm{prostrata} \mathrm{or} A$. aspera hot water extract was incubated at room temperature $\left(30 \pm 2{ }^{\circ} \mathrm{C}\right)$ for 8 minutes and the absorbance was recorded at $600 \mathrm{~nm}$. Six different concentrations of Trolox were used to construct the standard curve. Results were expressed as Trolox equivalents antioxidant capacity in mg Trolox equivalents per gram of extract on dry weight basis [10].

\section{Data analysis}

Data of each experiment were statistically analyzed using SAS software version 6.12. One way analysis of variance (ANOVA) and the Duncan's Multiple Range Test (DMRT) were used to determine the differences among treatment means. $\mathrm{P}<0.05$ was regarded as significant.

\section{Results and discussion}

Antioxidant activities of $C$. prostrata and A. aspera hot water extracts were evaluated by using in vitro assays: TPC, TFC, FRAP, DPPH and ABTS radical scavenging activity and ORAC. DPPH is a stable radical which gives a dark purple color at $517 \mathrm{~nm}$. When DPPH radical react with a antioxidant, its purple color is disappeared and gives pale yellow color at $517 \mathrm{~nm}$ [11]. In ABTS assay, ABTS and potassium per-sulphate produce ABTS radical cation which gives blue green color at $734 \mathrm{~nm}$. The green blue color of the ABTS radical will be converted to colorless when presence of antioxidants $[12,13]$. The capacity of a compound to scavenge peroxyl radicals was estimated in the ORAC assay. ORAC value is directly proportional to degree of antioxidant power [11]. FRAP assay can be used to measure the antioxidant power of compound/s [14].

According to the results, antioxidant activities of FRAP, DPPH and ABTS are almost similar in both C. prostrata and A. aspera. However, TPC, TFC and ORAC activities were higher in C. prostrata hot water extract than that of $A$. aspera. In vitro antioxidant activity of $A$. aspera grown in India was evaluated for different parts of the plant including stems, roots and leaves, roots, stems, leaves, inflorescence and leaves, stems, roots [15-18]. However, antioxidant activity was not evaluated for A. aspera grown in Sri Lanka. Similarly, antioxidant activity was evaluated for C. prostrata grown in Nigeria using the ethanol and methanol extracts prepared from the whole plant $[19,20]$.

In the present study, FRAP and DPPH scavenging activities of $C$. prostrata and A. aspera were not significantly different from each other. Moreover, ABTS scavenging activities of C. prostrata and A. aspera were almost similar to each other (Table 1). However, ORAC, TFC and TPC of C. prostrata was significantly higher than that of A. aspera (Tables 1 and 2). Secondary metabolites such as saponins, phenolic compounds, flavonoids and alkaloids were present in both plant extracts and glycosides were not found in either C. prostrata or A. aspera. In the present study, mg Trolox equivalents per gram of extract were significantly higher in ABTS assay than that of DPPH assay. This may be that DPPH assay is capable of measuring only the hydrophilic antioxidants whereas ABTS assay measures both hydrophilic and 
Table1. In vitro antioxidant activities of Cyathula prostrata Linn and Achyranthes aspera Linn

\begin{tabular}{|c|c|c|c|c|}
\hline & \multicolumn{4}{|c|}{ In vitro antioxidant assays } \\
\hline & $\begin{array}{c}\text { FRAP (mg Trolox equivalents/g of } \\
\text { extract) }\end{array}$ & $\begin{array}{l}\text { ORAC (mg Trolox equivalents/g } \\
\text { of extract) }\end{array}$ & $\begin{array}{c}\text { DPPH (mg Trolox equivalents/g of } \\
\text { extract) }\end{array}$ & $\begin{array}{c}\text { ABTS (mg Trolox equivalents/g of } \\
\text { extract) }\end{array}$ \\
\hline Cyathula prostrata Linn & $25.68 \pm 0.97^{\mathrm{a}}$ & $52.29 \pm 1.58^{\mathrm{b}}$ & $4.71 \pm 0.17^{\mathrm{d}}$ & $36.81 \pm 1.80^{\mathrm{e}}$ \\
\hline Achyranthes aspera Linn & $20.60 \pm 0.95^{\mathrm{a}}$ & $23.03 \pm 0.09^{c}$ & $4.24 \pm 0.17^{\mathrm{d}}$ & $32.01 \pm 0.24^{\mathrm{f}}$ \\
\hline
\end{tabular}

Data presented as mean \pm SEM. FRAP, ORAC, DPPH and ABTS $n=4$ each

Table 2. Total polyphenolic and Total flavonoid contents of Cyathula prostrata Linn and Achyranthes aspera Linn

\begin{tabular}{|l|l|l|}
\hline & $\begin{array}{l}\text { Total polyphenolic content } \\
\text { (mg gallic equivalents/g of } \\
\text { extract) }\end{array}$ & $\begin{array}{l}\text { Total flavonoid content } \\
\text { (mg quercetin equivalents/g } \\
\text { of extract) }\end{array}$ \\
\hline Cyathula prostrata Linn & $15.1 \pm 2.13$ & $9.60 \pm 0.10$ \\
\hline Achyranthes aspera Linn & $3.36 \pm 0.20$ & $2.86 \pm 0.60$ \\
\hline
\end{tabular}

Data presented as mean \pm SEM. $n=4$ each

lipophilic antioxidants [8]. According to Ibrahim and co-workers [20], C. prostrata grown in Nigeria had no antioxidant activity in $\mathrm{DPPH}$ assay. However, in the present study, C. prostrata grown in Sri Lanka has been shown an antioxidant activity in DPPH assay. Furthermore, almost similar quantity of phenolic compounds were present in $C$. prostrata grown in Nigeria $(16.95 \pm 3.32 \mathrm{mg}$ gallic acid equivalents/g extract) and Sri Lanka (Table 2).

\section{Conclusion}

Hot water extracts of $C$. prostrata and A. aspera have shown marked in vitro antioxidant activities. Antioxidant activities of FRAP, DPPH and ABTS are almost similar in both C. prostrata and A. aspera. However, TPC, TFC and ORAC activities were higher in $C$. prostrata hot water extract than that of $A$. aspera. Saponins, phenolic compounds, flavonoids and alkaloids were present in both C. prostrata and $A$. aspera. When considering the similarities of phytochemical constituents and antioxidant activities of two extracts, $A$. aspera can be used as a substitute for C. prostrata.

\section{References}

1. Gibbons CP, Bannister JJ, Read NW (1988) Role of constipation and anal hypertonia in the pathogenesis of haemorrhoids. Br J Surg 75: 656-660. [Crossref]

2. Ahad HA, Kumar CS, Reddy KK, Kranthi G, Mahesh K, et al. (2010) Herbal treatment for hemorrhoids. J Innov Trends Pharm Sci 5: 236-244.

3. Jayaweera DMA (2006) Medicinal plants (Indigenous and Exotic) Used in Ceylon, Part I, The National science foundation, Colombo, Sri Lanka.

4. Yadav RNS, Agarwala M (2011) Phytochemical analysis of some medicinal plants. $J$ Phytol 3:10-14.
5. Siddhuraju P, Becker K (2003) Antioxidant properties of various solvent extracts of total phenolic constituents from three different agroclimatic origins of drumstick tree (Moringa oleifera Lam.) leaves. J Agric Food Chem 51: 2144-2155.

6. Singleton VL, Orthofer R, Lamuela-Raventos RM (1999) Analysis of total phenols and other oxidation substrates and antioxidants by means of Folin - Ciocaltue reagents. Meth Enzymol 299: 152-178.

7. Blois MS (1958) Antioxidant determination by use of stable free radical: Nature 181: 1199-1200.

8. Re R, Pellegrini N, Proteggente A, Pannala A, Yang M (1999) Antioxidant activity applying an improved ABTS radical cation decolorization Assay: Free Radical Biol Med 26: 1231-1237.

9. Ou B, Hampsch-Woodill M, Prior RL (2001) Development and validation of an improved oxygen radical absorbance capacity assay using fluorescein as the fluorescent probe. J Agric Food Chem 49: 4619-4626.

10. Benzine IFF, Szeto YT (1999) Total antioxidant capacity of teas by the ferric reducing antioxidant power assay. J Agric Food Chem 47: 633-636.

11. Pisoschi AM, Negulescu GP (2011) Methods for total antioxidant activity determination: A review. Biochem Anal Biochem 1: 106.

12. Marc F, Davin A, Deglene-Benbrahim L, Ferrand C, Baccaunand M et al (2004) Studies of several analytical methods for antioxidant potential evaluation in food. Med Sci 20: 458-463.

13. Sreejayan M, Rao MN (1996) Free radical scavenging activity of curcuminoids Arzneimittel-forschung 6: 169-171.

14. Benzie IF, Strain JJ (1996) The ferric reducing ability of plasma (FRAP) as a measure of "antioxidant power": the FRAP assay. Anal Biochem 239: 70-76. [Crossref]

15. Priya CL, Kumar G, Karthik L, Rao KVB (2010) Antioxidant activity of Achyranthes aspera Linn stem extracts. Pharmacology Online 2: 228 -237.

16. Nehete JY, Deshmukh VN, Shewale VV, Narkhede MR, Aurangabdkar VM (2009) In vitro antioxidant activity of Achyranthes aspera L. J Pharm Res 2: 1402-1403.

17. Abi BG, Mohamed SA, Jaya SR (2011) Antioxidant and antibacterial activity of Achyranthes aspera: In vitro study. Ann Biol Res 2: $662-670$.

18. Kumar V, Jat RK (2017) Antioxidant activity of different extracts of various parts (leaves, stem and root) Achyranthes aspera. J Pharmacogn Phytochem 6: 1862-1865.

19. Oladimeji OH, Usifoh CO, Attih EE (2014) Novel antioxidant activity of Cyathula prostrata (L.) Blume. Eur Chem Bull 3: 352 -357.

20. Ibrahim B, Sowemimo A, Rooyen A, de Venter MV (2012) Anti-inflammatory, analgesic and antioxidant activities of Cyathula prostrate (Linn.) Blume (Amaranthaceae). $J$ Ethnopharmacol 141: 282-289.

Copyright: (C2018 Dissanayake DPA. This is an open-access article distributed under the terms of the Creative Commons Attribution License, which permits unrestricted use, distribution, and reproduction in any medium, provided the original author and source are credited. 